\title{
TEMPO E DOCÊNCIA: A FRAGMENTAÇÃO E INTENSIFICAÇÃO DO TRABALHO DOCENTE
}

\author{
NEPOMUCENO, Vera Lucia da Costa ${ }^{1}$
}

SILVA, Amanda Moreira da. Tempo e Docência: Dilemas, Valores e Usos na Realidade Educacional. Jundiaí, Paco Editorial, 2017. 176p.

Amanda Moreira da Silva é doutoranda em educação no Programa de PósGraduação em Educação da Universidade Federal do Rio de Janeiro (PPGE/UFRJ) e professora da Universidade do Estado do Rio de Janeiro (UERJ).

O livro é resultado de sua dissertação de mestrado e apresenta importante contribuição sobre a precarização e fragmentação do tempo do professor. Busca compreender os fatores que justificam a adesão de alguns professores da rede pública do Estado do Rio de Janeiro ao Programa Autonomia, abordando dilemas, contradições e estratégias que estes profissionais têm construído ao longo de suas trajetórias para minimizar o processo de proletarização.

No primeiro capítulo apresenta algumas definições que auxiliarão na análise do tempo na trajetória profissional dos docentes. Aponta a construção histórica da percepção do tempo na reestruturação rigorosa dos hábitos e disciplinas de trabalho que vem trazendo uma nova experiência, que passa a exercer uma coerção intensa na vida dos professores.

No segundo capítulo apresenta a legislação educacional como um campo de batalhas, revela a intensidade com que o Estado interfere no trabalho docente com leis que visam seus interesses, e como estes se apropriam deste universo legal. Articula as metas estabelecidas pela Secretaria Estadual de Educação e o Índice de Desenvolvimento da Educação do Rio de Janeiro (Iderj), com a remuneração variável do Programa de Bonificação por Resultados, dentro da lógica do Plano de Metas Compromisso Todos pela Educação.

No terceiro capítulo, referenciando se nas formulações de Thompson, analisa as respostas que estão sendo dadas aos desafios impostos a partir das experiências dos professores, o fazer-se no Programa. Com base nos relatos dos pesquisados, mostra como o trabalho docente vem sendo atravessado por processos de intensificação, de complexidade, de desprofissionalização, de performatividade, de

1 Doutoranda do Programa de Pós-Graduação em Políticas Públicas e Formação Humana da Universidade do estado do Rio de Janeiro, PPFH/UERJ. Pesquisadora do Grupo THESE - Projetos Integrados de Pesquisas sobre Trabalho, História, Educação e Saúde. e-mail: info_ver@hotmail.com 
DOI: $10.12957 /$ e-mosaicos.2018.33941

desqualificação e de proletarização. Observa no trabalho dos professores, a relação com os alunos, que se destaca e assume aspectos contraditórios, indicando questões relevantes para o debate das possibilidades de resistência e luta.

Considerando a complexidade dos elementos analisados em uma conjuntura tão adversa, a presente obra se revela como um inventário potente das tentativas de dominação e das possibilidades do seu enfrentamento que certamente auxiliará o campo da educação crítica na construção dos processos de resistência dos professores às tentativas de controle redutor de seu trabalho e da educação pública.

Recebido em 10 de setembro de 2017 Aceito em 04 de março de 2018 